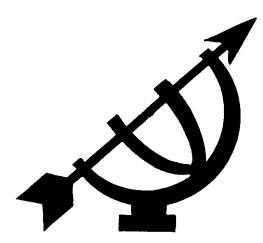

\title{
Professional development of teachers: Critical success factors
}

\author{
G.M.Steyn \& L.J. van Niekerk \\ School of Education \\ University of South Africa \\ PRETORIA \\ E-mail: steyngm1@unisa.ac.za \\ vnieklj@unisa.ac.za
}

\begin{abstract}
Professional development of teachers: Critical success factors

Professional development (PD) has attracted a great deal of attention in recent years. Despite research findings, the development of many $P D$ programmes often rests on faulty assumptions of such research or even no research at all. The purpose of this article is threefold: to explain why some PD programmes have been unsuccessful; to outline key factors that may influence the effective implementation of $P D$ and to explain the importance of contextual factors like environment, internal conditions and individual considerations as the major sources of momentum for PD in schools. Specific categories that are highlighted include the following: learning styles of educators, educator commitment, transformational leadership, out-of-school conditions, inschool conditions and requirements of PD programmes. The design of $P D$ requires a new way of thinking and interacting and, most importantly, should be a step towards improved learner performance.
\end{abstract}

\section{Opsomming}

\section{Professionele ontwikkeling van onderwysers: deurslaggewende faktore om sukses te behaal}

Professionele ontwikkeling het die afgelope aantal jare baie aandag ontvang. Ten spyte van navorsingsbevindings berus die ontwikkeling van professionele ontwikkelingsprogramme dikwels op foutiewe aannames van sodanige navorsing of selfs op geen navorsing nie. Die doel met hierdie artikel is drieledig: om te verduidelik waarom sommige programme misluk; om kernfaktore te identifiseer wat die effektiewe implementering van professionele ontwikkeling kan beïnvloed, en om die belangrikheid van kontekstuele faktore soos omgewing, interne toestande en individuele oorwegings, wat stukrag 
aan professionele ontwikkeling in skole gee, te beskryf. Spesifieke kategorieë wat beklemtoon is, sluit die volgende in: die leerstyle van opvoeders, toewyding van opvoeders, transformatiewe leierskap, buite-skoolse omstandighede, binne-skoolse omstandighede en die vereistes van professionele ontwikkelingsprogramme. Die ontwerp van professionele ontwikkelingsprogramme vir opvoeders vereis nuwe denke en nuwe wyses van interaksie wat ten doel het om die leerprestasies van leerlinge te verbeter.

\section{Introduction}

The training and development of human resources in organisations have never before been so important to society as today (Vincent \& Ross, 2001:36; Ho-Ming \& Ping-Yan, 1999:32). To meet evolving social needs, such as changing populations, economic conditions and changing industries, new learning systems are required (Vincent \& Ross, 2001:36). Emphasising learning and development ensures that learning processes contribute to the attainment of goals and the enhancement of quality and performance in organisations (Browell, 2000:57; Cullen, 1999:46). Unfortunately many reform initiatives ignore the people involved and concentrate primarily on the systems in which they work (Brinson, 1996:81). It is furthermore clear that professional development (PD) is caught up in a technicistfunctionalist paradigm with an emphasis on skills development. PD should be more than skills development or knowledge of a practical nature - it also relates to values and attitudes. Professional development is not something "done" to people. A person cannot be developed - professional development should be based on the awakening awareness or perhaps sudden realisation of one's inability or incompetence to perform according to one's own expectations or laid-down criteria.

Those engaged in PD should guard against a naive confidence that professional development is the answer to all problems experienced by teachers. In spite of all the activity on the education scene, teachers and students alike often share a feeling of utter helplessness. This feeling of despair and discouragement is especially true for those involved in schools in the Southern African context. The complexity of the education situation makes it very difficult for those involved to form a picture of their situation and to relate their own activities on a micro-level to the context as a whole. Because they find it difficult to establish a holistic perspective, teachers are at a loss to define their own roles in the situation (De Beer, 1994:6).

Somehow teachers and students need to develop the ability to unravel the complexities of education and to locate themselves 
within a framework or landscape that will allow them to move from being unaware to awareness (Van Niekerk \& Killen, 2000:78). Views on schools and education defy generalisation. It is too complex, too contradictory and composed of too many narrative strands.

In spite of years of public discourse about the state of schooling in the country one finds that very little has changed. Most of us would like to believe that great public debates are driven by serious intellectual concerns (Van Niekerk \& Killen, 2000:76). We would therefore like to believe that if academics and politicians are involved in discourse on education they must have something meaningful in mind. It seems far too cynical to suggest that the professional development of teachers is simply an instrument used by the state to train teachers in the implementation of new policies.

Sparks and Richardson (1997:3) even state that teachers will not change the way they teach unless they learn new ways to teach. Should this statement be found to be correct, then it is an indictment of initial teacher education.

To a large extent the problems experienced in education is the result of the general disdain for theory by most teachers and many of their educators. Educational theory is considered as somewhat useless. Theory, according to Kissack (1995:3) is associated with disparative, idealistic, impractical, nebulous, speculative and unverifiable issues. Practice, on the other hand, is considered as being concrete, specific, useful, practical and related to the real world. The gist of the problem is that theorists as well as practitioners have separated theory and practice, whereas theory denotes thought and action (Kelly, 1999:17). Theory is a reflection on practice itself whereas practice denotes the reality of teaching and learning.

In order to understand what happens in schools one can either work inductively, that is start with teaching and learning activities, or one can work deductively, and start with the role allocated to education institutions by society (Kelly, 1999:9). An inductive approach would require that the problematic issues concerning the role of the school in society, the participation of teachers and students, the nature of the curriculum and other aspects related to educational discourse be addressed at a local level . A deductive approach would lead us to examine any number of theories about the role of the school in society which would eventually give us an idea of how people think about the role of the school. The knowledge thus acquired we believe, would permit us to establish informed practices and to speculate further about the school and the role of teachers (Kelly,1999:9). 
The theory-practice relatedness which emerges in the deductiveinductive dualism does to some extent present itself in the textreader relationship. It is, however, in the hermeneutic circle, relating text and context, theory and practice (Danner 1995:16) that this apparent dichotomy is resolved. Many teachers' inability to reflect critically on their own practice and to try out new solutions to problems they encounter daily, necessitates continuing professional learning. PD therefore requires an inductive, problem-centred approach (Spector, 1993:4) that relate to teachers' context. Context in this sense includes a teacher's world view and concomitant philosophy of life that in turn will bear an influence on one's understanding of being a teacher.

\section{The need for professional development (PD)}

The way in which one talks about education, the school, teachers and learners will guide one's thinking and ultimately one's actions. Similarly, one's daily experiences will be articulated in language and give rise to thinking. All over the world various attempts to produce new and meaningful texts for education are implemented. When one considers the PD of teachers, one cannot ignore their context. International texts representing current thinking about PD should be related to the contexts of South African teachers, addressing their learning needs.

The ultimate aim of PD is increased learner performance, but individual learner outcomes and how educators teach learners are profoundly affected by the school culture in which educators work (King \& Newman, 2001:87). These conditions imply that professional learning communities in which teachers and leaders work together and focus on student learning are required (Purkey \& Strahan, 1995:4; Sparks, 2003b:55). However, individual factors, and contextual factors external to the school and PD itself could also play an important role in creating learning communities. From this perspective designing a PD programme should be grounded not only on an abstraction in the way educators learn, but should consider the factors which could influence the effective implementation of PD. These factors not only impact on the effectiveness of $P D$, but should result in more meaningful learning experiences for learners.

Schools are pressurised to "produce more for less" and at the same time to achieve certain goals and standards (Robinson \& Carrington, 2002:239). Unless schools become places for teachers to learn, 
they cannot be places for student learning (Bernauer, 2002:91). PD of educators is seen as an essential ingredient for creating effective schools and improving learners' performance (Rhodes \& HoughtonHill, 2000:424; Wood \& Millichamp, 2000:513; Birman et al., 2000:32). Despite research findings, many PD programmes are developed on faulty assumptions of such research or even on no research at all (Burke, 1997:299).

Since educators have the most direct contact with learners as well as a considerable control over what is taught and how it is taught, it can be assumed that to enhance educators' knowledge, skills and attitudes is a critical step in improving learner performance (King \& Newman, 2001:87; Ribisch, 1999:121; Anon., 2001/2002:17). It is necessary to realise that educators cannot hope to use the most sophisticated approach to student learning unless they have both the skills to use it and the desire to implement it (Shaw, 2003:39).

Valuable contributions to the understanding of PD have already been made. Yet, there remains much within this field of study that is unclear and incomplete. In particular, the major factors influencing the effectiveness of PD are relatively unexplored, although some studies do focus on single factors influencing PD. This article attempts to satisfy three objectives: first, to explain why some PD programmes have been unsuccessful; second, to outline key factors that may influence the effective implementation of PD, and third, to explain the relative importance of external environment, internal conditions and individual factors as the major sources of momentum for PD in schools. The purpose is not to outline all the factors that influence $P D$, but to suggest that diverse factors may have an influence on PD. In order to identify significant factors, it is important to survey existing research in this regard and develop a suitable model to indicate such factors.

\section{What is professional development?}

All professions require a continuous update of knowledge and skills (Sparks \& Richardson, 1997:2; Somers \& Sikorova, 2002:103). The teaching profession is no exception. It is universally acknowledged that a teacher's professional training does not end at the stage of initial pre-service training (Ho-Ming \& Ping-Yan, 1999:32; Somers \& Sikorova, 2002:96).

Since PD has become more diverse than ever, it covers a variety of activities that are designed to enhance the growth and professional competence of staff members (Campbell, 1997:26; Adams, 1997:4). 
Research also indicates that longer-term, team-oriented learning approaches are replacing passive workshops and lectures by experts (Sachs, 1999:23; cf. Rhodes \& Houghton-Hill, 2000:433; Brandt, 2003:13). The focus of these learning approaches is the continuous reflection on and renewal of professional knowledge, skills and attitudes required of teachers so that all learners can learn and perform at higher levels (Browell, 2000:57; Sparks \& Richardson, 1997:2; Ho-Ming \& Ping-Yan, 1999:39; Somers \& Sikorova, 2002:103). It is difficult for learners to attain high levels of learning unless their teachers are continuously learning (Sparks \& Richardson, 1997:2). The aim of attaining higher levels of learning implies that educator learning and learner learning go hand in hand (Wood \& Millichamp, 2000:499).

PD helps teachers to acquire the most up-to-date knowledge of the subjects they teach and to use techniques that are powerful in enhancing student learning (Sparks \& Richardson, 1997:3; Rhodes \& Houghton-Hill, 2000:424; Browell, 2000:59). However, the responsibility of each staff member is more than keeping up to date (Dixon, 1998:164). It is a responsibility to experiment continually, deliberately reflect on what has happened as a result of the individual or team effort, and reflect with others on the action of the whole system in order to learn how to improve. In this sense PD has to resonate with a teacher's desire to change existing practice.

PD is most effective when it is an ongoing process that includes suitable properly planned learning programmes and individual follow-up through supportive observation and feedback, staff dialogue and peer coaching (Campbell, 1997:26; Ho-Ming \& PingYan, 1999:40; Moore quoted in Robinson \& Carrington, 2002:239; Anon., 1999:390; Bernauer, 2002:89; Moore, 2000:14). A teacher development project, "Learning effectiveness and equity program" conducted at Mary MacKillop College, has reported success due to the presence of these variables (Campbell, 1997:27). A tendency exists to underestimate the long-term commitment of professional development that is required for effective change to take place (Robinson \& Carrington, 2002:239; Blackmore, 2000:3; Richardson, 2003:401). In this process educators develop a greater sense of collaboration, share common problems, and assume greater responsibility for their own professional development (Ribisch, 1999:116; Bernauer, 2002:90; Browell, 2000:59). Furthermore, PD is more powerful when it is conducted long enough and often enough so that continuous gains are made in self-confidence, knowledge and skills (Robinson \& Carrington, 2002:239; Somers \& Sikorova, 2002:103). 
Considering the above, PD relates to lifelong development programmes that focus on a wide range of knowledge, skills and attitudes in order to educate students more effectively. PD includes both formal and informal activities carried out by an individual or an organisation to enhance staff growth. In this complex process educators improve and develop their teaching skills, and their curriculum development, implementation and evaluation skills (Conners quoted in Campbell, 1997:26). PD has the potential to influence educator learning, but the reality is that there have been many wasteful workshops, conferences and seminars that have led to little sustained change in classrooms (Russell, 2001:3).

There should be a realisation that PD is not simply about "doing the right things" or "doing things right" but also about understanding what it means to be a teacher - being a teacher - and understanding the needs of teachers.

\section{Conventional models of PD: Why don't they work?}

Conventional PD has not substantially improved learner performance, because these approaches violate key principles for educator learning. The following can be regarded as key principles:

- Educator learning is most likely when educators can concentrate on teaching and learner outcomes in the specific contexts they teach (King \& Newman, 2001:87). Educators often view PD material as unrelated to student learning in their particular setting and therefore do not apply what PD offers (King \& Newman, 2001:87).

- Educator learning is most likely to happen when educators have sustained opportunities to learn, to experiment with and to receive feedback on specific changes they make (King \& Newman, 2001:87; Moore, 2000:14; Redding \& Kamm, 1999:29; Robinson \& Carrington, 2002:239). Unfortunately most PD programmes consist of brief workshops, conferences, or courses that do not allow for follow-up sessions (King \& Newman, 2001:87; Richardson, 2003:401).

- Educator learning is most likely to happen when educators have opportunities to work with professional peers, both inside and outside their schools, along with access to the expertise of researchers and programme presenters (King \& Newman, 2001:87; Robinson \& Carrington, 2002:240; Ho-Ming \& Ping-Yan, 1999:36). Peer collaboration and support are required for PD to 
be effective (Rhodes \& Houghton-Hill, 2000:431; Anon., 2001/ 2002:18; Brandt, 2003:10; Richardson, 2003:401; Bernauer, 2002:89; Washington, 1993:252; cf. Gerber, 1998:170). Conventional PD programmes have relied almost exclusively on outside specialists controlling learning without incorporating these resources into existing knowledge and systems of peer cooperation (Robinson \& Carrington, 2002:239).

- Educator learning is most likely to happen when teachers have influence over the content and process of PD (King \& Newman, 2001:87; Badley, 1992:17; Ho-Ming \& Ping-Yan, 1999:36; Bernauer, 2002:91). For many educators PD is a mind-numbing experience in which they passively "sit and get" (Sparks, 1997:20). By empowering educators it facilitates a sense of ownership or "buy-in" that promotes internalisation of learning (King \& Newman, 2001:87). Teacher ownership is crucial for PD effectiveness (Anon., 1999:388; Ho-Ming \& Ping-Yan, 1999:32; Sparks, 2003b:58; Blackmore, 2000:3).

Although experts acknowledge the importance of PD in school reform efforts that seek high levels of learning for all learners, many PD programmes continue to leave educators' knowledge and skills untouched (Sparks, 1997:20). Considering the above, PD programmes should therefore change if they have to prepare staff to meet certain academic standards successfully and improve learner performance (Sparks, 1997:20).

A crucial question is: What factors play a role in the effective and meaningful implementation of PD for educators? Figure 1 provides an outline of some factors that will influence the impact of PD programmes. The following major categories are identified: teachers' commitment to change; learning styles; transformational leadership; out-of-school conditions; in-school conditions and personal factors. How each of these categories impacts on PD is briefly described in the following paragraphs.

Since PD in effect means that staff members are learning and developing new knowledge, skills and attitudes for the sake of enhancing learner performance, such programmes need to consider the learning styles of individual staff members. Research reveals the existence of individual differences between adult learners that may impact on their learning (Burke, 1997:299). 


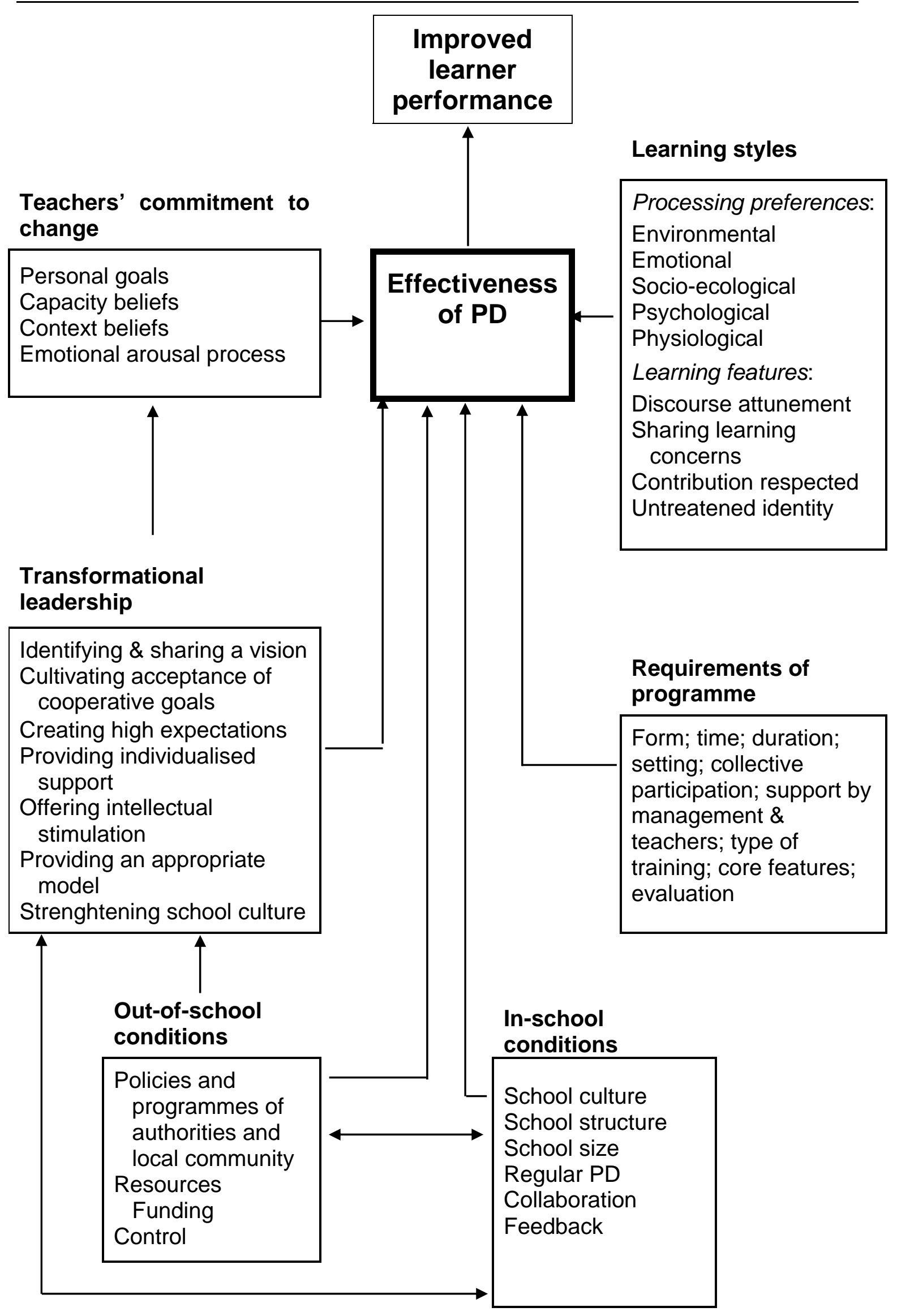

Figure 1: Factors influencing professional development 


\section{Learning styles of educators}

For effective PD the different learning styles of participants should be identified (Burke, 1997:299). This identification implies personalising training sessions and taking learning styles into consideration during training sessions (Vincent \& Ross, 2001:42). Teachers are individuals with specific learning needs and learning styles (Robinson \& Carrington, 2002:240; Somers \& Sikorova, 2002:108). Teachers who learn in programmes that accommodate their preferences will acquire more skills, become more motivated and apply what they learn in the classroom (Burke, 1997:301).

Learning styles include a number of variables, such as an individual's environmental, emotional, socio-ecological, psychological and physiological processing preferences.

- Environmental factors: Environmental factors include a comfortable and well-equipped venue (Burke, 1997:300; Ribisch, 1999: 119).

- Emotional factors: Since adults prefer to be involved in their own learning for the sake of personal ownership, they should participate in setting goals, priorities, processes and the evaluation of PD (Burke, 1997:300; Badley, 1992:17; Ho-Ming \& Ping-Yan, 1999:36; Bernauer, 2002:91).

- Sociological factors: Although lecturing has long been an acceptable mode of instruction, it has to include other techniques except those aimed at auditory, listen-alone learners (Burke, 1997:300). According to Burke (1997:300) and Ribisch (1999: 117) effective PD implies maximising staff interaction through small-group discussions that could stimulate their learning and provide motivation. In Tyrell's view (2000:16) teachers do not want to be lectured, but prefer to be inspired by observing an expert performing a task.

- Psysiological factors: When planning for PD the different physiological needs of teachers should be considered, such as the time of the day, type of food and beverage preferences (Burke, 1997:300). Learning styles are also related to physiological factors: auditory (hearing), visual (seeing) and tactual (touching) sense-impressions (Vincent \& Ross, 2001:41). Staff developers should therefore design auditory, visual, tactual and kinesthetic material and match them with each learner's strengths (Burke, 1997:300; Vincent \& Ross, 2001:41). Tyrell (2000:16) supports this view by stating that programmes should be 
individualised and fully differentiated. Unfortunately such programmes can be costly and time-consuming to implement.

Apart from the variables listed above, Ashworth (quoted in Smith \& Coldron, 1999:255) identifies four key features of learning:

- Attunement to others' discourse. The way in which educators participate in PD from the standpoint of their own backgrounds should be acknowledged (Smith \& Coldron, 1999:255; Somers \& Sikorova, 2002:108). Educators' background includes the tradition in the particular school and the subject they teach, as well as personal beliefs and values (Smith \& Coldron, 1999:255). Teacher learning most likely occurs when PD takes the diverse needs of learners in the specific context of their classrooms into account (Robinson \& Carrington, 2002:240; Ho-Ming \& Ping-Yan, 1999:36; Bernauer, 2002:91; Sachs, 1999:26; Mashile, 2002:174; Somers \& Sikorova, 2002:108; cf. Guskey, 2002:50).

- Sharing emotionally in concerns relevant to learning. An essential feature of participation is that individuals see themselves as having the right to voice their opinions and to be listened to (Smith \& Coldron, 1999:255; Somers \& Sikorova, 2002:104).

- Being assured that they can contribute appropriately and worthily. Participants need to feel respected for what they know and can do and they should be treated accordingly in PD (Smith \& Coldron, 1999:255; Somers \& Sikorova, 2002:104).

- Being relatively unthreatened concerning one's identity. Many teachers faced with changes in curricula may feel that their threshold of competence has been threatened by having to adjust their methods. For some it could be a source of growth, but support and sensitivity are, however, needed from those initialising and stimulating change (Smith \& Coldron, 1999:255).

It is clear from the above that different contexts and different learning styles may require different techniques (Anon., 1999:388; Guskey, 2002:50). Consequently, professional learning should offer various opportunities for teachers to construct their own meaning and theories in a collaborative setting (Novick quoted in Robinson \& Carrington, 2002:240). PD has to be individualised to the extent that it builds on each teacher's experience and expertise while also providing the basic knowledge that developing professionals require to succeed (Partee \& Sammon, 2001:15).

Since the focus of PD programmes is on educator learning, it can be deduced that teacher commitment will play a crucial role in their 
development (Yu, Leithwood, \& Jantzi, 2000:369; Pehkonen \& Törner, 1999:262; Blackmore, 2000:3; Bernauer, 2002:90).

\section{Educator commitment}

Compared to the school's commitment to change, teachers' commitment is equally if not more important for the success of PD (Ho-Ming \& Ping-Yan, 1999:38; Pehkonen \& Törner, 1999:262; Blackmore, 2000:3). According to Ho-Ming and Ping-Yan (1999:38) PD will be futile without teachers' wholehearted commitment, even if such programmes are well designed.

Yu et al. (2000:369) describe the different aspects of teachers' commitment to develop professionally as follows:

- Personal goals: These goals refer to the desired future states internalised by an individual. As an important source of teacher commitment, they must be observed by teachers to energise action.

- Capacity beliefs: These beliefs refer to psychological states such as self-efficacy, self-confidence, academic self-concept and aspects of self-esteem. Teachers must also believe that they are capable of accomplishing goals. The study of Lam and Pang (2003:90) illustrates that when educators are more confident about themselves, they are more prepared to be involved in learning.

- Context beliefs: These beliefs refer to whether the school environment, such as the school governance structure, will provide funds, professional development or other resources for teachers to effectively implement changes in their classroom practices.

- Emotional arousal process: The functions of this process are to create a state of "readiness" to activate immediate action and to maintain action.

Law (quoted in Rhodes \& Houghton-Hill, 2000:432) suggests a model for exploring the relationship between staff commitment to PD and leadership. According to him, a collaborative culture in schools is considered to be conducive to both PD of teachers and the facilitation of learner achievement (Rhodes \& Houghton-Hill, 2000:432). Yu, Leithwood and Jantzi's model (2000:369) on teachers' commitment to change explicitly identifies the effect of leadership on teacher commitment. 


\section{Transformational leadership}

Quality leadership is required for effective PD in schools (Bernauer, 2002:89). Quality leadership provides an orderly and nurturing environment that supports teachers and stimulate their efforts (Bernauer, 2002:90). A skill associated with an effective leader is to inspire people to work more effectively and to obtain ownership (Mahoney, 1998:98). Thus, Mahoney (1998:96) states: "Successful leaders are able to commit people to action." Current trends in leadership show a shift from bureaucratic managerial styles to leadership styles that reflect human dignity and promote collaboration in decision-making (Campbell, 1997:27; Asbill \& Gonzalez, 2000:15). With such leadership styles principals are visionaries, form collegial relationships with staff, and share knowledge with them (Edwards, Green \& Lyons, 2002:69). According to Fullan (quoted in Sparks, 2003b:58), creating and sharing knowledge is central to effective leadership. If principals do not share leadership with teachers, development and staff empowerment will be unlikely to occur (Bernauer, 2002:89; Edwards et al., 2002:68).

Transformational forms of leadership fundamentally aim to make events meaningful, cultivate professional development and higher levels of commitment to organisational goals on the part of staff ( $\mathrm{Yu}$ et al., 2000:370; Bernauer, 2002:90). The model used in the Canadian study condicted by $\mathrm{Yu}$ et al. (2000) includes various transformational leadership dimensions that could influence teacher commitment and have an effect on PD. These dimensions and their usefulness are also supported by other researchers. They are:

- Charismatic leadership: Identifying and sharing a vision. Charisma is a characteristic that describes leaders who are able to exert a profound influence on followers, the school's performance and climate by the force of their personality, abilities, personal charm, magnetism, inspiration and emotion (Dubrin \& Ireland, 1993:280; Dreher, 2002:207). Charismatic leadership also provides a vision and a sense of mission (Mester et al., 2002:73). A vision is critical for PD effectiveness (Anon., 1999:388; Richardson, 2003:401).

- Cultivating the acceptance of cooperative goals. Creating a community of learners requires the cultivation of shared values and the development of an appreciation for the value of working together and caring about one another (Robinson \& Carrington, 2002:241; Bernauer, 2002:90). The shared values of members in 
a school community affect their actions that subsequently have an influence on the school culture (Smith \& Coldron, 1999:252; Robinson \& Carrington, 2002:241; Wood \& Millichamp, 2000: 499). Principals play a major role in transforming norms, values, beliefs and assumptions of staff and subsequently affect the way in which they make decisions (Lam \& Pang, 2003:84).

- Creating high-performance expectations. Expectations like these refer to leaders' expectations for excellence, quality and high performance on the part of staff members (Anon., 2001/2002:18).

- Providing individualised support. Support of this kind refers to demonstrations of respect for individuals and concern about their personal feelings and needs (Yu et al., 2000:370). The way in which teachers are supported through the process of change is important (Sachs, 1999:26; Robinson \& Carrington, 2002:239; Brandt, 2003:10; Gerber, 1998:170; Richardson, 2003:401). It is also important to provide emotional, psychological and logistical support to educators to enable them to continue developing new habits during the implementation dip that reduces effectiveness before new procedures become routine (Sparks, 2003a:43; Somers \& Sikorova, 2002:103; Pehkonen \& Törner, 1999:260; Anon., 1999:388; Somers \& Sikorova, 2002:103; Anon., 2001/ 2002:18; Washington, 1993:252).

- Offering intellectual stimulation. This kind of stimulation challenges teachers to reexamine certain assumptions of their practices and rethink how they could be accomplished (Yu et al., 2000:370). Such stimulation creates a gap between the current and desired practices and could enhance emotional arousal processes (Somers \& Sikorova, 2002:111; Mester et al., 2002:73).

- Providing an appropriate model. Examples which are consistent with values leaders advocate, are set for staff members to follow (Yu et al., 2000:371).

- Strengthening school culture. A school's culture has far more influence on life and learning in schools than the president of the country, the department of education, the principal, teachers and parents can ever have (Barth quoted in Sparks, 2003b:56). School culture therefore has the power to influence and shape professional learning and learner performance (Campbell, 1997:27; Sparks, 2003b:56). Leadership is important in establishing a positive school culture (Campbell, 1997:27). Without effective leadership, in particular transformational leadership, efforts to change school culture, and influence educator 
commitment will most likely fail (Bernauer, 2002:90). Such behaviour encourage teacher commitment through their effect on teachers' understanding of the shared school goals (Mahoney, 1998:97).

Apart from the crucial effect of leadership on PD, the conditions within a school can play an important role in the effectiveness of PD.

\section{In-school conditions}

The Canadian study conducted by Yu et al. (2000) include mediating variables such as school culture, school structure, strategies for change, and school environment that may affect teacher commitment to change. Since teacher commitment will impact on PD, it can be deduced that these variables may also impact on PD. Research also reveals some other variables concerning in-school conditions that may influence the effectiveness of PD.

- School culture: This term refers to the shared norms, values, beliefs and assumptions shared by role players of an organisation that shape decision-making and practices (Yu et al., 2000:370; Duff quoted in Lowrie \& Smith, 1998:7). This definition has particular implications for PD since it implies not only that PD needs to be congruent with school culture, but also that culture is "taught" and therefore PD programmes themselves have some involvement in transmitting the school's particular culture (Lowrie \& Smith, 1998:7; Somers \& Sikorova, 2002:111). The initial condition for effective PD should be a positive school culture, otherwise valuable time and resources will be spent in achieving only minor growth of staff members (Campbell, 1997:27). School culture also should have a humane character, that is, it should be psychologically comfortable with warm human relationships and professionally supportive systems where people have the resources they need and opportunities to collaborate and learn from others (Brandt, 2003:15; Partee \& Sammon, 2001:15; Somers \& Sikorova, 2002:103; Anon., 2001/2002:18).

- School structure: This variable refers to opportunities for teachers in decision-making concerning classroom and school-wide practices. The school structure supports shared and distributed leadership that has the potential for teachers to believe that they are empowered to shape meaningful and feasible changes in the school (Campbell, 1997:27; Washington, 1993:252). Unfortunately most changes fail because leaders do not share the leadership with teachers (Bernauer, 2002:90). 
- School size: The size of the school appears to be an important factor for planners of PD (Lowrie \& Smith, 1998:14; Smith \& Coldron, 1999:252). In larger schools where extensive staffdevelopment activity exists, many individual teachers appear to be relatively uninvolved with development (Lowrie \& Smith, 1998:14). On the contrary, teachers appear to be more involved in smaller schools. The professional background of teachers and cultural norms may, however, also have an influence (Lowrie \& Smith, 1998:14).

- Regular PD: Since ongoing development is a characteristic of effective PD, it is obvious that such programmes should be presented on a regular basis.

- Collaboration: Teacher collaboration and support are required for PD to be effective (Rhodes \& Houghton-Hill, 2000:431; Anon., 2001/2002:18; Brandt, 2003:10; Richardson, 2003:401). Unfortunately the traditional culture of teacher isolation in many schools and the limited time available for interaction within schools have not encouraged teachers to cooperate as colleagues (Ribisch, 1999:116; Trent, 1997:108; Collinson, 2001: 267).

PD should provide opportunities for teachers to discuss their achievements and problems in employing new strategies (Robinson \& Carrington, 2002:240; Bernauer, 2002:90). By doing so, the collaboration will contribute towards the development of a positive school culture that is committed to change and the creation of better learning opportunities for all (Robinson \& Carrington, 2002:240; Rhodes \& Houghton-Hill, 2000:431).

- Feedback: Staff development is most effective when it is a continuous process that includes individual follow-up through supportive observation and feedback, staff dialogues, mentoring and peer coaching (Moore, 2000:14; Robinson \& Carrington, 2002:239; Richardson, 2003:401).

Schools do not operate in a vacuum, but is part of a larger system in which they have to meet goals set by authorities.

\section{Out-of-school conditions}

In a survey of educational environments across countries, uniformity and the acceleration of change that are reshaping the nature of schools' external environment are evident (Lam \& Pang, 2003:83). 
These external environments have undergone radical changes from the "familiar institutional environment to the more turbulent taskrelated environment" (Hoy \& Miskel quoted in Lam \& Pang, 2003:84). Institutions are therefore forced to enter into collaborative enterprises and strategic partnerships with domestic or international partners due to globalisation with its concomitant competition (Mashile, 2002:175; Brandt, 2003:16). State policies concerning globalisation have consequently influenced sectors closely linked to the state, such as education. These factors have influenced national economies in various ways, but their influence on individuals will differ (RSA, 2001:5). One should keep in mind, however, that demands for skills and a better educated workforce, that is PD, will rather increase than decrease across all sectors, including education.

As seen from the above, conditions outside schools have the potential to influence the functioning of schools which may impact on PD in schools. The following factors are highlighted:

- Policies and programmes of authorities: Schools are strongly influenced by changing of control patterns, enrolment fluctuations and policy directives from the education department (Lam \& Pang, 2003:92). Schools that were regulated by the education department in the past, have to readjust their working procedures with decentralisation, that may impact on PD.

- Resources: The quality of teaching and learning depends on people and structural and technical resources that are influenced by community context and policies, and programmes of other external role players (King \& Newman, 2001:88).

- Funding: Planning for continuous PD implies the availability of necessary funding. Funds to support PD may be provided by educational authorities, outside agencies or raised by individual schools.

- Control: Responding to change through PD can keep teachers seemingly busy, but makes them dependent where others control their actions (Lowrie \& Smith, 1998:7). Control of this kind is in contrast to empowerment, where teachers take control of change processes (Richardson, 1992:287; Lowrie \& Smith, 1998:7; Edwards et al., 2002:68; Englehardt \& Simmons, 2002:45).

The preceding paragraphs have outlined numerous factors that may impact on the meaningful implementation of PD. The influential role of PD itself cannot be ignored. 


\section{Critical success factors}

For PD to be meaningful and effective certain structural aspects are important.

- Form: Traditional approaches are criticised for not giving teachers the time, activities and the content to improve their knowledge and skills (Birman et al., 2000:29). For PD to be effective, programmes should be longer, have more content focus, active learning and coherence (Birman et al., 2000:29).

- Time: Quick fixes may not produce the desired results (Blackmore, 2000:4). Teachers need blocks of time without responsibilities for optimal learning to take place (Anon., 1999: 388). There seems to be different views on the time provided for PD. According to Shelton and Jones (1996:99), time for PD should be provided after school hours. They found that training at the end of a school day has been proven useful for follow-up sessions to focus on special topics. This is in contrast to the findings of Washington (1993:252) that indicates that teachers prefer to have workshops during school hours. Time slots after school, weekends and holidays were viewed as the least desirable times to offer PD programmes (Washington, 1993:252). In essence, these respondents believe that teachers' personal time should be respected (Washington, 1993:253).

- Duration: PD should take place over an extended period of time (Birman et al., 2000:29; Blackmore, 2000:3; Richardson, 2003: 401; Russell, 2001:3).

- Collective participation: Collective participation may contribute to a shared professional culture where teachers develop the same values and goals (Birman et al., 2000:30; Bernauer, 2002:90; Cullen, 1999:46; Drejer, 2000:208). A study uncertaken by HoMing and Ping-Yan (1999:40) indicates that the establishment of a culture of learning and sharing is more conducive to PD. Sharing stimulates teachers' reflection and broadens their perspective (Ho-Ming \& Ping-Yan, 1999:40; Dixon, 1998:164; Blackmore, 2000:3; Shelton \& Jones, 1996:100).

Table 1 presents a summary of the relationship between components of PD and the impact on teachers' work performance (Rhodes \& Houghton-Hill, 2000:432). Without putting theory into practice, any PD programme is limited to being superficial (Ho-Ming \& Ping-Yan, 1999:39). It is interesting to note that high-level and efficient transfer is only achieved when coaching is added to the equation (Rhodes \& Houghton-Hill, 2000:431; Ho-Ming \& Ping-Yan, 
1999:40). A barrier in this respect is the lack of teacher collaboration and support from leaders or other colleagues in realising the impact in the classroom (Rhodes \& Houghton-Hill, 2000:431; Anon., 2001/ 2002:18; Brandt, 2003:10). Lack of teacher collaboration and of support imply that principals have a crucial role to play in offering effective leadership in PD aimed at lasting changes in classrooms (Bjork, 2000:25; Lam \& Pang, 2003:84).

Table 1: The relationship between components of training and impact on educators' performance (Rhodes \& Houghton-Hill, 2000:432)

\begin{tabular}{|c|c|c|c|}
\hline \multirow[t]{2}{*}{$\begin{array}{l}\text { Training components and com- } \\
\text { binations }\end{array}$} & \multicolumn{3}{|c|}{$\begin{array}{l}\text { Impact on teachers' job } \\
\text { performance }\end{array}$} \\
\hline & $\begin{array}{l}\text { Knowl- } \\
\text { edge }\end{array}$ & Skill & $\begin{array}{l}\text { Trans- } \\
\text { fer }\end{array}$ \\
\hline Theory & Low & Low & Nil \\
\hline Theory and demonstration & Medium & Medium & Nil \\
\hline Theory, demonstration and practice & High & Medium & Nil \\
\hline $\begin{array}{l}\text { Theory, demonstration, practice and } \\
\text { feedback }\end{array}$ & High & Medium & Low \\
\hline $\begin{array}{l}\text { Theory, demonstration, practice, } \\
\text { feedback and coaching }\end{array}$ & High & High & High \\
\hline
\end{tabular}

According to Dixon (1998:164) it is the responsibility of each team and individual to make what they have learnt available to others. This view implies that it is assumed that a staff member or team takes the responsibility for sharing knowledge. Studies indicate that although teachers value the sharing of their knowledge, finding available time is a great barrier (Dixon, 1998:166). This view is also supported by Collinson (2001:270). Collinson (2001:271) therefore suggests that designated time for learning and sharing should be instituted in schools to improve the quality of information dissemination.

- Support of management and teachers: For programmes to be effective, both management and teachers have to support these programmes (Richardson, 2003:401). Washington's study (1993: 252), however, indicates that teachers felt that principals' 
involvement in PD should be limited to a supportive role and that of a participant in PD programmes. Principals' attendance communicates they value the programme (Washington, 1993:252).

- Type of training: The type of training should be applicable to teachers' practice (Shelton \& Jones, 1996:99). Outside providers often use inappropriate activities that are not geared to classroom learning (Shelton \& Jones, 1996:99). Although it is widely acknowledged that learners learn differently, schools neglect to apply this concept to PD, using a one-size-fits-all approach (Shaw, 2003:40).

One should, however, consider that such evaluations of PD programmes do not prove that $P D$ is effective. The relationship between PD and improvement in student learning is much too complex and includes many variables (Guskey, 2002:49). The complexity of PD leads Harry Gray (1997) to remark that "a good teacher is simply someone who wants to be a good teacher". No amount of professional development will change teachers' behaviour unless they want to be good teachers.

\section{Conclusion}

Ongoing professional development is essential if quality education to learners is to be provided (Louw, 1992:1). Drucker (quoted in DuFour \& Berkey,1995:5) elaborates on this view by stating that successful organisations of the twenty-first century will be learning organisations that build continuous learning into jobs at all levels. No pre-service training programme can effectively prepare people for a lifetime in organisations. Moreover, the skills and knowledge of educators can decline over time. As such a need exists for educators to be regularly, if not continually, involved in quality programmes of development for the sake of improving learner performance. Unfortunately many programmes that are offered to educators are inadequate and do not attain their goals. Many programmes impose texts on educators that alienate them from their context. Professional development should enable educators to develop their own texts that link with their context. This requirement implies that it is necessary to revisit PD in order to identify factors that will influence its appropriateness and effectiveness.

Conceptual clarity is a developmental characteristic of fields of study, also that of PD. The process to achieve clarity depends upon accumulated knowledge. As a field of study, PD is well developed to have accumulated a considerable level of knowledge (Evans, 
2002:135). Much of the research on PD has made valuable contributions to the understanding of PD, but little attention has been devoted to addressing the serious question: What are the major factors that influence the effectiveness of PD? If these major factors are not addressed satisfactorily, many other PD issues may be inadequately examined. Knowledge of such factors has the potential to inform and influence policy and practice. It may give rise to questions such as: What does the PD process involve? What are the effects of PD on the education system? How might the PD be effected? (Evans, 2002:135). These questions also provide a framework for further research. The latter is required if identifying the factors influencing PD is to fulfil its potential for developing theory that will make a meaningful contribution to policy and practice.

This article examined factors that may impact on the effectiveness and meaningfulness of PD for educators. Specific categories highlighted include learning styles of educators, educator commitment, transformational leadership, out-of-school conditions, inschool conditions and requirements of programmes. According to the model for PD, the design of PD requires a new way of thinking and interacting and, most importantly, should be a step in the direction of improved learner performance.

\section{List of references}

ADAMS, M. 1997. Staff development: Perspectives on the future. National Association of Staff Development Journal, 37:4-7, June.

ANON. 1998. The concept of invitational education. Journal of Developmental Education, 22(1):38, 39, Fall.

ANON. 1999. Professional staff development: A key to school improvement. NCA-Quarterly, 73(3):387-391, Winter.

ANON. 2001/2002. New staff development standards issued. Reading Today, 19(3):17-18, Dec. 2001/Jan. 2002.

ANON. 2003. Igniting your learning approach: How to encourage deeper learning in your organization. Development and Learning in Organizations, 17(2):21-23.

ASBILL, K. \& GONZALEZ, M.L. 2000. Invitational leadership: Teacher perceptions of inviting principal practices. Journal of Invitational Theory and Practice, 7(1):14-27.

BADLEY, G. 1992. How (not) to evaluate a staff development workshop? National Association of Staff Development, 27:7-22, June.

BERNAUER, J. 2002. Five keys to unlock continuous improvement. Kappa Delta Pi Record, 38(2):89-92, Winter. 
BIRMAN, B.F., DESIMONE, L., PORTER, A.C. \& GARET, M.S. 2000. Designing professional development that works. Educational Leadership, 57(8):28-33, May.

BJORK, C. 2000. Responsibility for improving the quality of teaching in Japanese schools: The role of the principal in professional development efforts. Education and Society, 18(3):21-43.

BLACKMORE, J. 2000. Developing conditions to teacher professional renewal. Teacher Learning Network, 7(1):3-5, Summer.

BRANDT, R. 2003. Is this school a learning organization? 10 ways to tell. Journal of Staff Development, 24(1):10-17.

BRINSON, K.H. 1996. Invitational education as a logical, ethical and democratic means to reform. Journal of Invitational Theory and Practice, 4(1):81-94.

BROWELL, S. 2000. Staff development and professional education: A cooperative model. Journal of Workplace Learning, 12(2):57-65.

BURKE, K. 1997. Responding to participants' learning styles during staff development. Clearing-House, 70(6):299-301, July/Aug.

CAMPBELL, B. 1997. Professional development: Beyond the on-day serving. The Practising Administrator, 19(2):26-28.

COLLINSON, V. 2001. "I don't have enough time" - Teachers' interpretations of time as a key to learning and school change. Journal of Educational Administration, 39(3):266-281.

CULLEN, J. 1999. Socially constructed learning: A commentary on the concept of the learning organisation. The Learning Organization, 6(1):45-52.

DANNER, H. 1995. Hermeneutics in educational discourse: Foundations. (In Higgs, P., ed. Metatheories in educational theory and practice. Johannesburg: Heinemann. p. 175-200.)

DE BEER, C.S. 1994. Epistemology of knowledge utilisation. Paper delivered at the conference on "Research at Unisa: an interfaculty deliberation" - 16 March 1994. Pretoria.

DIXON, N.M. 1998. The responsibilities of members in an organization that is learning. The Learning Organization, 5(46):161-167.

DREHER, E.D. 2002. Leading the Toa: The energizing power of respect. The Learning Organization, 9(5):206-213.

DREJER, A. 2000. Organisational learning and competence development. The Learning Organization, 7(4):206-220.

DUBRIN, A.J. \& IRELAND, R.D. 1993. Management and organization. 2nd ed. Cincinnati: South-Western College Division.

DUFOUR, R. \& BERKEY, T. 1995. The principal as staff developer. Journal of Staff Development, 16(4):2-6, Fall.

EDWARDS, J.L., GREEN, K.E. \& LYONS, C.A. 2002. Personal empowerment, efficacy, and environmental characteristics. Journal of Educational Administration, 40(1):67-86.

ENGLEHARDT, C.S. \& SIMMONS, P.R. 2002. Creating an organizational space for learning. The Learning Organization, 9(1):39-47.

EVANS, L. 2002 . What is teacher development? Oxford Review of Education, 48(1):123-137.

GERBER, R. 1998. How do workers learn in their work? The Learning Organization, 5(4):168-175.

GRAY, H. 1997. Personal interview. 24 August 1997, University of South-Africa.

GUSKEY, T.R. 2002. Does it make a difference: Evaluating professional development. Educational Leadership, 59(6):45-51, March. 
HO-MING, N.G. \& PING-YAN, C. 1999. School-based teacher development in Guangzhou, China. International Studies in Educational Administration, 27(2):32-42.

KELLY, A.V. 1999. The curriculum: Theory and practice. 4th ed. London: Chapman.

KING, M.B. \& NEWMAN, F.M. 2001. Building school capacity through professional development: Conceptual and empirical considerations. The International Journal of Educational Management, 15(2):86-94.

KISSACK, M. 1995. Hermeneutics in education: Reflections for teachers of the humanities. (In Higgs, P., ed. Metatheories in philosophy of education. Johannesburg: Heinemann. p. 245-261.)

LAM, Y.L.J. \& PANG, S.K.N. 2003. The relative effects of environmental, internal and contextual factors on organisational learning: The case of Hong Kong schools under reforms. The Learning Organization, 10(2):83-97.

LOUW, D.C. 1992. Differentiated staff development: A case study. Paper presented at The Second National Educational Management Congress, 1012 September.

LOWRIE, T. \& SMITH, E. 1998. Staff development in the V.E.T. sector: Case studies of two providers. Australian Journal of Teacher Education, 23(2):516.

MAHONEY, J.A. 1998. The inviting school superintendent. Journal of Inviting Theory and Practice, 5(2):97-105.

MASHILE, E. 2002. Continuous professional development for educators: The state, professional councils and higher education. South African Journal of Higher Education, 16(1):174-182.

MESTER, C., VISSER, D., ROODT, G. \& KELLERMAN, R. 2002. Leadership style and its relation to employee attitudes and behaviour. Industrial Psychology, 29(2):72-82.

MOORE, K.B. 2000. Successful and effective professional development. Scholastic Early Childhood Today, 15(3):14-16, Nov./Dec.

PARTEE, G.L. \& SAMMON, G.M. 2001. A strategic approach to staff development. Principal Leadership, 1(6):14-17.

PEHKONEN, E. \& TÖRNER, G. 1999. Teachers' professional development: What are the key change factors for mathematics teachers? European Journal of Teacher Education, 22(2-3):259-275.

PURKEY, W.W. \& STRAHAN, D. 1995. School transformation through invitational education. Researching in the Schools, 2(2):1-6.

REPUBLIC OF SOUTH AFRICA. 2001. The national skills development strategy. Skills for productive citizenship for all. The Minister of Labour, February 2001. http://www.labour.gov.za/docs/sp2001 [14 August 2003].

REDDING, J.C. \& KAMM, R.M. 1999. Just-in-time staff development: One step to the learning organization. National Association for Secondary School Principals, 83(604):28-31.

RIBISCH, K.H. 1999. The facilitator as agent of change. English Language Teaching Journal, 53(2):115-121, April.

RICHARDSON, V. 1992. The agenda-setting dilemma in a constructivist staff development process. Teaching \& Teacher Education, 81(36):287-300.

RICHARDSON, V. 2003. The dilemmas of professional development. Phi Delta Kappa, 84(5):401-406, Jan. 
RHODES, C. \& HOUGHTON-HILL, S. 2000. The linkage of continuing professional development and the classroom experience of pupils: Barriers perceived by senior managers in some secondary schools. Journal of InService Education, 26(3):423-435.

ROBINSON, R. \& CARRINGTON, S. 2002. Professional development for inclusive schooling. International Journal of Educational Management, 16(5):239-247.

RSA

see REPUBLIC OF SOUTH AFRICA

RUSSELL, P. 2001. Professional development: Making it effective. Teacher Learning Network, 8(3):3-7, Spring.

SACHS, A. 1999. Solid foundation: NSDC standards are the rock of Maryland schools to build on. Journal of Staff Development, 20(1):23, 24, 26-28, Winter.

SHAW, T. 2003. Professional development potluck: Successful programs offer a dish for every taste. Multimedia Schools, 10(2):39-41, March/April.

SHELTON, M. \& JONES, M. 1996. Staff development that works! A tale of four T's. NASSP Bulletin, 80(582):99-105, Oct.

SMITH, R. \& COLDRON, J. 1999. Conditions for learning as teacher. Journal of In-Service Education, 25(2):245-260.

SOMERS, J. \& SIKOROVA, E. 2002. The effectiveness of in-service education on teachers course for influencing teachers' practice. Journal of In-Service Education, 28(1):95-114.

SPARKS, D. 1997. A new vision for staff development. Principal, 77(1):20-22, Sept.

SPARKS, D. 2003a. Skill building. Journal of Staff Development, 24(1):29, Winter.

SPARKS, D. 2003b. Change agent. Journal of Staff Development, 24(1):55-59, Winter.

SPARKS, D. \& RICHARDSON, J. 1997. A primer on professional development. Journal of Staff Development, 18(4):1-8.

SPECTOR, B.S. 1993. Order out of chaos: Restructuring schooling to reflect society's paradigm shift. School Science and Mathematics, 93(1):9-19.

TRENT, L.M.Y. 1997. Enhancement of the school climate by reducing teacher burnout: Using an invitational approach. Journal of Invitational Theory and Practice, 4(2):103-114.

TYRELL, K. 2000. Professional development in education: More questions than answers. Education Review, 14(1):14-17, Autumn.

VAN NIEKERK, L.J. \& KILLEN, R. 2000. Recontextualising outcomes-based education. South African Journal of Higher Education, 14(3):90-100.

VINCENT, A. \& ROSS, D. 2001. Personalize training: Determine learning styles, personality types and multiple intelligence online. The Learning Organization, 8(1):36-43.

WASHINGTON, K.R. 1993. Teacher initiated staff development: What do principals and teachers think? School Organization, 13(3):251-253.

WOOD, E.K. \& MILLICHAMP, P. 2000. Changing the learning ethos in school. Journal of In-Service Education, 26(3):499-515.

YU, H., LEITHWOOD, K. \& JANTZI, D. 2000. The effects of transformational leadership on teachers' commitment to change in Hong Kong. Journal of Educational Administration, 40(4):368-389. 


\section{Key concepts:}

professional development: external, internal and individual factors professional development: key factors for effective implementation professional development (PD) for educators professional development programmes: reasons for failures

\section{Kernbegrippe:}

professionele ontwikkeling: eksterne, interne toestande en individuele faktore professionele ontwikkeling: faktore by effektiewe implementering professionele ontwikkeling (PO) vir opvoeders professionele ontwikkelingsprogramme: redes vir mislukkings 
